\title{
nature
}

\section{Desperately seeking a syndrome}

The US Congress should stop pushing researchers to invent a medical definition for Gulf War syndrome, the collection of maladies associated with veterans of the 1991 conflict in the Persian Gulf.

$\mathrm{O}$ $\mathrm{n}$ frequent occasions in recent years, groups of experts have been appointed to answer the question: is there a Gulf War syndrome? Is there a link between the chemicals, medicines and other materials to which troops were exposed in the conflict and their subsequently reported long-term health problems? The answer, in a recent Institute of Medicine (IoM) study (see Nature 407, 121; 2000) and in all previous such excursions on both sides of the Atlantic, has been a polite but firm "no".

But last week in the US Senate the appropriations subcommittee for labour, education and health, chaired by Senator Arlen Specter (Republican, Pennsylvania), held a hearing on the issue. The IoM study was requested by the Congress to determine, on the basis of an extensive literature review, whether any of the veterans' health problems could reasonably be attributed to their exposure to nerve gas, depleted uranium or vaccines and other medication administered during the conflict. It found that, although some of these exposures could be linked to acute symptoms, there was insufficient evidence to link any of them to chronic health problems.

Specter and Senator Kay Bailey Hutchison (Republican, Texas) used their hearing to advise senior government officials that they should acknowledge what Hutchison termed "the clear commonsense evidence" that the syndrome does exist. But as John Feussner, head of research at the Department of Veterans Affairs, bluntly put it: "The problem with declaring that there is a GulfWar syndrome is that the research suggests that there is not."

One of the star witnesses at the hearing was Ross Perot, erstwhile presidential candidate of the Reform Party and champion of veterans' causes. Perot has financed the work of Robert Haley, an epidemiologist at the University of Texas Southwestern Medical Center at Dallas, who believes that he has established several possible links between symptoms reported by a small cohort of veterans and their possible exposure to several different chemicals during the conflict (see Nature 385, 187; 1997). The government has supported Haley's work too, to the tune of $\$ 3$ million.

Haley argues, justifiably, that the early study of epidemics should concentrate on the close observation of symptoms in small selfselected groups. But Harold Sox, professor of medicine at Dartmouth-Hitchcock Medical Center in New Hampshire and chair of the recent IoM study, told the senators that Haley's studies which were published in the Journal of the American Medical Association almost four years ago - have yet to be independently replicated. Peer-review panels established by the government have rejected Haley's request for a $\$ 25$ million follow-up project.

One benefit of the efforts to pin down GulfWar-related illness has been their exposure of the military brass's tendency to downplay the physical and mental impact of war on all of its participants. In future, governments will accept more responsibility for the long-term welfare of returning troops.

In the meantime, there will be no let-up in the political campaign to push for a medical definition of Gulf War syndrome. But as the scant data on who was exposed to what in 1991 fade into the mists of time, scientific grounds for such a definition may well never emerge. The Congress may wish to establish an administrative classification for the health problems afflicting veterans. But it should stop pressing scientists in effect to invent findings that would support its otherwise admirable impulse to assist them.

\section{Systems biology's multiple maths}

Modelling cellular systems will be a key element of post-genomics science.

$\mathrm{M}$ ost readers of this publication will know that "postgenomics" and "proteomics" are phrases that mean little that is specific but herald an encyclopaedic era of information about the way biological cells and their genes and proteins behave. But how best to make sense of it all? It is, at last, possible to anticipate mathematics becoming useful in the modelling of the systems. And in that spirit it would be hard to be more ambitious than the efforts of Leroy Hood's Institute for Systems Biology, in Seattle, and Al Gilman's Alliance for Cellular Signalling, based in Dallas.

Hood aims to synthesize gene expression, protein expression and protein interaction into models of specific cell processes, such as immune responses (see page 828). Gilman's consortium aims to characterize every protein-protein interaction in two cell types, then turn the data into a cellular wiring diagram (see Nature 407, 7; 2000).

The projects differ both in dimension and scope. Hood's approach, for now at least, straddles several levels of data in a smaller system, whereas Gilman's effort sticks to one level of data in a larger system. These differing emphases will no doubt determine the kinds of models that will emerge from each effort. Gilman's "virtual cell" would seem best represented by a series of differential equations, as protein-protein interactions are characterized in a linear fashion. Hood's approach appears to demand different kinds of maths perhaps forms that capture the probabilities of different cellular elements being simultaneously engaged, or algorithms that account for constantly fluctuating cellular conditions.

But such programmes don't come cheap. Gilman's centre has already received $\$ 25$ million over five years from the US National Institutes of Health and is seeking an additional \$25 million from private sources. Hood is amassing a $\$ 200$ million endowment for his institute. The centres' different approaches complement each other well. But such work is embryonic, and the two centres could well need to exploit each other's developments as each evolves. They could also need to alter their emphasis as more protein and gene information becomes available in the next few years. But provided they and others like them maintain their flexibility to adapt, they should achieve a long-awaited development when mathematics does what it has so often done in other disciplines: provide a basis for prediction and thereby lead rather than lag behind the experiments. 